\title{
Review of Tourism Geography to Preservation of Barong Ider Bumi Cultures in Banyuwangi Regency Indonesia
}

\author{
Moch. Nurfahrul Lukmanul Khakim ${ }^{1 *}$, Nailul Insani ${ }^{2}$, Restia Minati Anggraeni ${ }^{1}$, \\ Eka Tanti Nur Lailah ${ }^{1}$
}

\author{
$1^{1 *}$ Departement of History, Faculty of Social Science, Universitas Negeri Malang, Malang, East Java, Indonesia \\ ${ }^{2}$ Departement of Geography, Faculty of Social Science, Universitas Negeri Malang, Malang, East Java, Indonesia
}

\begin{abstract}
Kemiren Village, one of the cultural tourism villages in Banyuwangi, has a unique tradition that is usually held every year. This tradition is often referred to as Ider Bumi or Barong Ider. Barong Ider is the main attraction for tourism. The aims of this study are: (1) knowing the Kemiren Village as the village that owns the culture, (2) knowing the Barong Ider Bumi tradition, (3) knowing the development of Barong Ider Bumi as a tourist attraction based on a Geography Tourism perspective. The method of this research is qualitative descriptive. Research steps start from determining the issues, observation, library research, and interviews. Data analysis was done by using the Geography Tourism perspective. Kemiren cultural tourism village seeks to maintain the authenticity of their ancestral culture and traditions. With the authenticity and wisdom of their culture, it becomes the main attraction for tourists. Although many new cultures are coming in, their culture and traditions are still very awake. The Kemiren Village Community made various improvements in terms of public services for tourists without changing the authenticity of their culture. Tourism Geography Study explained that's the cultural tourism of Barong Ider Bumi, which has attracted tourists by providing tourist facilities properly. Barong Ider Bumi, as cultural tourism, produces various advancements and improvements in terms of economic and social life in Banyuwangi.
\end{abstract}

Keywords: Barong Ider Bumi, cultural tourism, preservation ways.

\section{INTRODUCTION}

Indonesia has a variety of cultural heritages spread across various provinces, especially East Java. Cultural heritage is a legacy of the past in the form of physical culture (tangible) and cultural values (intangible). The cultural heritage of a community in an area is created through history over a long period of time that has been passed down from generation to generation [1]. One of the regencies in East Java that has a thick cultural heritage is Banyuwangi. Cultural heritage can be interpreted as a product or physical cultural product of different traditions and spiritual achievements in the form of values from the past that are a central element in the identity of a group or nation [2]. The cultural heritage of the Banyuwangi community is seen in sacred rituals and arts.

The cultural values of the past (intangible heritage) are covered by local cultures in Indonesia, including traditions, social system, folklore and legends, languages, performing arts (dance, songs, drama performances). This intangible heritage has been reflected in the relation between humans and their geography

\footnotetext{
Correspondence address:

Moch. Nurfahrul Lukmanul Khakim

Email : moch.nurfahrul.fis@um.ac.id

Address : Universitas Negeri Malang, Jl. Semarang No. 5, Lowokwaru, Malang, Jawa Timur, KP 65145
}

area/environment [3]. The geographical study of tourism has a long history and a well-established relationship with human geography [4]. Physiogeographic phenomena (elements of the physical environment) and sociogeographical phenomena (elements of the human or social and cultural environment) that have uniqueness, beauty and value, are interesting to visit so that they develop into tourist destinations [5].

Cultural heritage in a traditional society can be reflected in the pattern of settlement. Cultural elements are the main elements forming residential patterns and architectural styles of residential buildings. One of the cultural heritages found in Banyuwangi Regency is Barong Ider Bumi. Kemiren is a village located in the Glagah area. This village became the village of the Osing tribe, a native of Banyuwangi.

This area is known as one of the national cultural heritage areas. As a tourist village, Kemiren Village always holds a unique tradition that is usually known as the Barong Ider Bumi. The Barong Ider Bumi tradition is said to have become so ingrained in the life of the Osing tribe. This unique cultural heritage is said to be up to hundreds of years old. This tradition experiences turmoil in the midst of a rapid change of times. The community is trying to preserve this tradition so that it does not go extinct [6]. Community synergy as an effort to preserve this tradition becomes an interesting study object. The 
objective of the research is to describe the development of Barong Ider Bumi as a tourist attraction based on the Geography Tourism perspective.

\section{MATERIAL AND METHOD}

The research method used in this study is qualitative descriptive. Qualitative research is research that focuses on studies supported by a variety of methods that include a naturalistic interpretation approach to the subject of the study [7]. Subjects of qualitative research studies include the collection of various empirical data, case studies, interviews, observational texts, and various ways of collecting data. Researchers collect information through various data collection procedures such as literature review observations as well as from previous research. The obtained information was explained descriptively. Collecting information in the field is also complemented by literature reviews that are relevant to the topic and issues in this research. The main problem of this research is about cultural tourism and efforts to preserve the Barong Ider Bumi tradition.

\section{Data Collection}

The research area in this study covers the Banyuwangi district area in Kamiren village, Glagah. Kemiren village is one of the cultural tourism villages, which is one of the leading destinations in the Banyuwangi Regency [8]. This limitation is due to the lack of resources regarding Barong Ider Bumi and the originality of the Barong Ider Bumi culture in Banyuwangi. Regardless if there is a Barong Ider Bumi culture elsewhere, then it will not be included in our research discussion. The effort to preserve the Barong Ider Bumi culture is related to the role of society and the present context. Data collection was carried out through a literature study and interviews with cultural activists of Barong Ider Bumi.

\section{Data Analysis}

One of the studies in the field of tourism geography is culture. Tourism geography research focuses on tourism resource data ranging from natural resources, human resources, and human creation resources. Natural resource data is in the form of the Banyuwangi environment that supports Barong Ider Bumi tourism. Human resource data is in the form of human interaction in organizing the Barong Ider Bumi culture. Data on human resources is in the form of the ongoing process of the Barong Ider Bumi ritual. Data analysis was carried out by understanding the concepts and cultural scope of Barong Ider Bumi, so observations and interviews were conducted with Barong Ider Bumi activists. Literature study data is used to strengthen observational data. Observation data is used to support the interview data. All of this data is used to develop Barong Ider Bumi tourism in Banyuwangi.

\section{RESULT AND DISCUSSION}

\section{Kemiren Village of Banyuwangi, Indonesia}

Kemiren Village is a small village located in the Glagah Subdistrict, Banyuwangi Regency, East Java Province. This village is $10 \mathrm{~km}$ from the center of the Banyuwangi Regency. This village has been designated as a tourist village since 1995. Within the administrative area, this village is bordered by Jambesari Village in the north, Olehsari Village in the south, Tamansari Village in the west, and Banjarsari Village in the east. This village has an area of 177.05 hectares $[9,10]$.

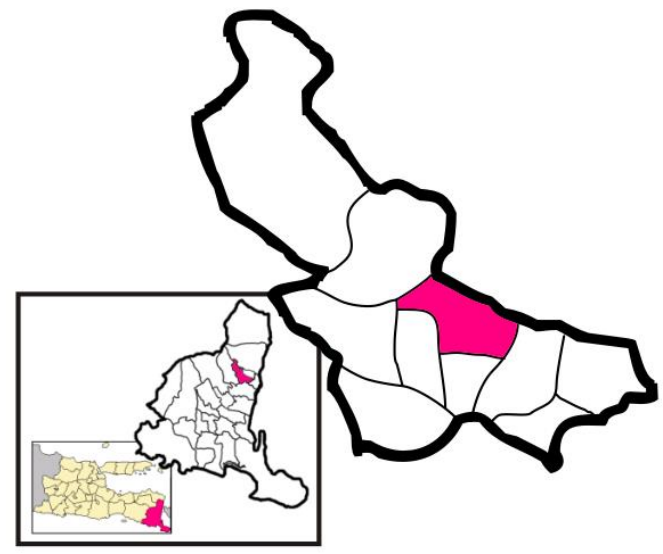

Figure 1. Maps of Kemiren Village, Banyuwangi, East Java, Indonesia (Source: www.kemiren.com)

The people of Kemiren Village came from people who had exiled themselves from the Majapahit Kingdom, which collapsed around 1478 AD. They retreated to Mount Bromo (Tengger Tribe), Bali, and Banyuwangi. Those who fled to Banyuwangi then founded the HinduBuddhist-style Blambangan Kingdom. Blambangan later fell to the rule of the Islamic Mataram Kingdom in 1743 AD.

Kemiren Village was born during the Dutch colonial period around 1830. At that time, the condition of Kemiren Village was still in the form of rice fields and forests belonging to residents of Cungking Village. To avoid Dutch soldiers in their village, residents of Cungking Village were reluctant to return to their villages. Cungking villagers chose to cut down their rice fields and 
forests at that time so that they became Kemiren Village until now [11]. When cleared by residents of Cungking Village, many of the Candlenut and Durian trees were found in that place, hence the place was called Kemiren (Personal Communication, 2014).

\section{Barong Ider Bumi}

Barong Ider Bumi Ritual is a ritual in the Village of Kemiren. This ritual was held as an expression of gratitude for the safety of all members of the Kemiren Village community. The word ider in Javanese means to go around everywhere, while bumi means a beachhead [12]. So, the meaning of the ider bumi is the activity around the foothold, in this case, into the area of the Kemiren Village [13]. The Barong Ider Bumi tradition first emerged from one of Buyut Cili. Buyut Cili is a propagator of Islam in Blambangan and clearing the base (forest clearing) into Kemiren Village. After successfully mastering Blambangan, suddenly, Buyut Cili, whose name is unknown, disappeared, and no one knew his whereabouts until now.

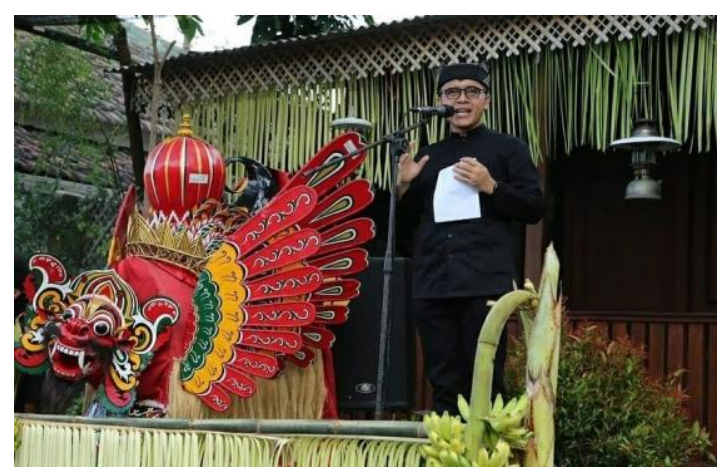

Figure 2. Barong Ider Bumi (Source: www.kemiren.com)

Finally, the local residents built fireworks to appreciate their services, and then they were called Buyut Cili by villagers. This Cili word in Osing (Banyuwanginesse) means little or tiny. Once, Buyut Ciliwanted to entertain his grandchildren on the second day of Eid al-Fitr by holding a barong procession that surrounds Kemiren Village. Buyut Cili is delighted while holding the palm and following the barong procession around the village. This event was later named Barong Ider Bumi (Personal Communication, 2019).

The background to the reappearance of this tradition is inseparable from myth when there was a plague of calamity. People were sick in the afternoon, then they died at the next day morning, and people's plants were attacked by pests. Even the villagers did not dare to sleep alone but rather in groups. Finally, the village elders made a pilgrimage to the tomb of Buyut Cili. After a few days, the village elder named Mbah Sanemah received instructions through a dream from Buyut Cili to look for two polek poles (Alstonia scholaris).

A short polek wood was put in the well so that the plague is gone, but the plague did not disappear. The village elder also had a second dream, which contained an order to take wood from the well to be made into the barong head and to hold a slametan ceremony. The barong head must also be paraded through the village streets. After the prophecy was carried out, the plague disappeared. One day the villagers never carried out the ritual. As a result, the owner of the barong became ill and convulsions, like barong movements and faces until he died. Therefore, the ritual is routinely carried out until now $[10,13]$.

The Ider Bumi Ritual was held on the second day of Eid al-Fitr at noon around 15:00 WIB because the weather at that hour was not too hot. It is a form of syncretism that is a mixture of Islam with elements of local Javanese culture [14]. The element of Islamic culture is seen at the time of the ritual implementation, which is the holy day of Islam as the majority religion of Kemiren Village residents. Meanwhile, Javanese local culture elements can be seen in the use of offerings placed in three different places, namely in the ancestors' tomb, Barong's house, and the Kemiren village road. There is also a sequence of participants in the Ider Bumi ritual, including:

1. At the front, two people are carrying Kemiren banners, wearing Banyuwangi clothes, namely tulik clothes.

2. A group of Barong arts, which begins with a pair of tiger dancers, are standing on the right and left side that goes casually without attractions. Behind them, a pair of pitikpitikan (chicken plays) with the right position are walking while dancing. Behind a pair of chicken costumes, the position of the main character is Barong Ider Bumi, who walked while dancing, followed by a music group.

3. Modin is village officials in the field of religion whose job is to sow offerings accompanied by customary stakeholders. This section is followed by children who fight for a sprinkling of offerings containing money.

4. The group of mothers dressed in typical Using Keiren with offerings, Kinangan, and 
water put in Kendhi (jar) is placed in brass bowls carried with a carry.

5. Jebeng-tulik group is the youth with typical Banyuwangi clothing. Jebeng brought offerings of red and white rice jenang with water. Tulik has the duty to accompany the Jebeng by bringing an umbrella to protect offerings from the sun.

6. Tumpeng carrier groups.

7. The jaran kecak group, a horse that runs by moving its head and footsteps to the rhythm of music that rode by a government official and a child.

8. Tambourine music groups that wear Muslim clothing.

9. Ladies group of PKK in traditional dress.

10. A group of village officials with distinctive clothing.

11. Kuntulan, a music group whose voice sounds dominant in rituals, and

12. Community groups who follow the ritual journey as cheerleaders.

The procession begins by arranging the order of participants, and then they start walking from Barong's house then crossing the main village road. When the procession took place, there was a traditional figure from the ritual group who was doing utilities or throwing coins in the street for kids to compete with the amount of IDR 99,000. The number was chosen because of the symbol of Asmaul Husna or the good name of Allah, which numbered 99. During the parade, the barong in front of the line, followed by village elders. Village elders bring incense and recite prayers for the safety of all residents. The procession was accompanied by the wasps of distinctive Using music, which made the ritual so sacred and solemn.

The community will fight over bananas that are displayed when the procession reaches the end of the village. They believe that anyone who eats bananas will be saved and will be provided with convenience in life. After the ritual, the community held a pecel pitik salvation, prayed and ate chicken together. Pecel Pitik is a traditional food from young native chicken, which is burnt and given spices of grated young coconut and spices typical of the Osing tribe. The salvation begins with the reading of the Osing prayer followed by Arabic, as a statement of intention to hold a selametan (thanksgiving) and continue eating together $[10,13]$. The barong procession takes place after the Asr Prayer at 15:00 to 17:00 WIB before the Maghrib Prayer.
The implementation starts with a simple ritual in the Barong house and ends with a ritual of ngalap blessing (selametan) or a thanksgiving party with all the residents [11], followed by a meal with all residents (Personal Communication, 2014). Barong Ider Bumi has philosophical significance for the life of the people, especially the people of Kemiren Village.

Barong is a distinctive form of art that is still preserved by the Banyuwangi community, especially the Kemiren village community. Banyuwangi people use barong as one of the ritual media in carrying out the barong ider bumi ceremony. Barong Ider Bumi is considered as a sacred art that appeared around the 1800s due to the pagebluk (Javannesse; plague) that caused many disasters in the area, e.g. disease and crop failure. Therefore, this ritual is carried out as a belief that aims to drive away evil spirits and calamities that occur so as not to recur by getting safety and happiness in the next life. An understanding of this ritual shows that Kemiren villagers maintain cultural heritage. The cultural heritage of a community in an area is formed through a long history that has been passed on from generation to generation [1].

Barong Ider Bumi heritage has become a tradition inherent in the Banyuwangi community. Therefore, the art is still preserved because of the ancestral heritage, even though the religion of the villagers today is Islam, which does not teach belief in sacred objects. In this case, the Banyuwangi community has shown a cultural value. The concept of cultural value itself is the concepts that live in the minds of the majority of the community about things that must be considered very valuable in life [15].

Values emerge that indirectly influence integration in society through cultures and traditions that have lasted for generations. These values are (1) as a recommendation for social control, as a venue for friendship to reduce conflicts that can arise at any time in the community; (2) the ritual can increase people's confidence in navigating the future life [16]. In the development, the traditional rituals implementation in the village is increasingly well known and began to be designated as a tourism village of Osing by government in the 1900s [16].

The endorsement of the village of Kemiren as a tourism village has influenced the initial function of the barong. Barong function which was previously only a traditional ceremony. Now, it developed into an art that is also used in weddings, circumcisions, and guest greetings. 


\section{Efforts to Preserve Barong Ider Bumi in Tourism Geography Review}

Apart from the stipulation of the local government, which states that the village of Kemiren is a tourist village, the art has improved the economy in the Banyuwangi area, especially the Kemiren area. The trigger for this economy is the large number of tourists visiting the Kemiren cultural tourism village, which is supported by the awareness and strong desire of the community in preserving and developing tourism in their area. Successful tourism development is a tourism development that is conducted together, including building together with the community so that tourism development can provide economic, social, and cultural benefits to the local community [17].

It makes the village and the arts more known and an increase in tourism in terms of economic and social. The economic improvement of Kemiren Village community can be seen from the number of tourist accommodation facilities, parking services, food shops and souvenirs, public toilets. Socially, efforts to preserve the tradition appear in the emergence to teach anyone, including tourists who want to learn about the tradition of Barong Ider and other traditional dances.

Tourism geography is the study of geography that is closely related to tourism, including weather, natural beauty, flora, fauna, sea, customs, and so on [18]. Barong Ider Bumi entered in the customs in the study of tourism geography. The relationship between the environment and various forms of tourism is fundamental. Since an area is formed, the existence of environment can be interpreted physically or in socio-cultural designation can directly influence the formation of the tourism geography process [19].

Barong ider as part of the tourism geography, especially cultural attraction, is only found in the Kemiran Village of Banyuwangi Regency because of the cultural and physical environment surrounding it. Therefore, barong ider as an art of cultural heritage should indeed continue to be preserved.

Cultural tourism is tourism that aims to broaden insights about other countries/cultures and to satisfy entertainment needs such as exhibitions, traditional celebrations, places of nature reserves, ancient reserves, and others [20]. Barong Ider Bumi as cultural tourism is not only seen as a ritual but has indeed become a customary practice of the people of Kemiren
Village to carry out the tradition. The government and the community work together to preserve Barong Ider Bumi. Barong Ider Bumi preservation is manifested in the following efforts:

\section{Studio}

Studio (Sanggar) is one of the important efforts by the people of Kemiren Village to preserve the Barong Ider Bumi. This studio is used to practice dance for young people there. The young people there must indeed be able to master the dances that are typical of Kemiren Village. Besides, they also practice special dances to accompany Barong Ider. By involving young people in preserving Barong Ider, it is hoped that the preservation of the culture can continue to develop from generation to generation.

\section{Annual Cultural Event}

The Kemiran community has the awareness to preserve Barong Ider Bumi in Banyuwangi because it is an annual village clean ceremony that must be held (Personal Communication, 2019). The annual cultural event is an event held by the local government. The event takes place once a year and usually includes various festivals in it. The event is one of the efforts of the Banyuwangi local government to preserve the culture of Barong Ider. The government is committed to paying attention to traditional culture because the preservation of Barong Ider is also one of the attractions of cultural tourism.

3. The improvement in public services

The improvement in public services is related to the determination of Kemiren Village as a tourist village. It has increased public facilities and services, such as the availability of public toilets, restaurants, lodging places, souvenir centers, tour guides, and others. The improvement in facilities and services aims to make tourists more comfortable and impressed when visiting Kemiren Village. The facilities and services are expected to increase tourist attraction and the number of visitors who travel to the Village of Kemiren.

Improvement of this facility can be developed by villagers, such as cultural actors and tourism resources by collaborating with government or private parties [21]. These facilities include providing an information center office/studio about Barong Ider Bumi 
in the village office or the home of a traditional stakeholder. Tourism stakeholder also need to promote the Barong Ider Banyuwangi through online and social media to attract investors attention to the development and increase the number of tourist [22]. This facility can serve the needs of tourists regarding information, event schedules, and accommodation places to enjoy the cultural tourism of Barong Ider Bumi. In the study of tourism geography, facilities, such as hotels, restaurants, transportation facilities, souvenir centers, and proper road access are needed to improve the quality of cultural tourism in the village of Kemiren, Banyuwangi Regency Indonesia.

\section{CONCLUSION}

Kemiren Village in Banyuwangi Regency is a cultural tourism village that still maintains the authenticity of cultural and ancestral traditions. Barong Ider Bumi has its attraction for tourists because geographically, it has interesting tourism potential. Although many new cultures entered, the culture of Barong Ider Bumi is still very awake. The people of Kemiren Village have made various improvements in terms of public services for tourists without changing the authenticity of the Barong Ider culture. Tourism Geography Study can support the cultural tourism of Barong Ider Bumi, which has attracted tourists by providing adequate tourist facilities. As a result, the cultural tourism of Barong Ider Bumi is expected to contribute to progress and increase in terms of economic and social aspects of the Banyuwangi community.

\section{ACKNOWLEDGEMENT}

Author thank the Departement of History, Faculty of Social Science, Universitas Negeri Malang. We also thanks Ahmad Hibatullah Habibi Al Asari, Roni Suryansyah, Mr. Indra as member of Pokdarwis (Kelompok Sadar Wisata/Tourism Awareness Group) Kemiren Village, and Mr. Purwadi as a chieftain in Kemiren Village Banyuwangi.

\section{REFERENCES}

[1] Karmadi, A. D. 2007. Budaya lokal sebagai warisan budaya dan upaya pelestariannya. Paper in Cultural Dialog of West Java. The Yogyakarta Traditional History and Values Preservation Center - The Education and Culture Office of Central Java Province, Semarang.
[2] Davidson, G. and Mc. Conville. 1991. A heritage handbook. Allen and Unwin. St. Leonard, NSW.

[3] Ardiwidjaya, R. 2018. Arkeowisata: mengembangkan daya tarik pelestatrian warisan budaya. Deepublish. Yogyakarta.

[4] Saarinen, J. 2014. Tourism geographies: Connections with human geography and emerging responsible geographies. Geographia Polonica 87(3), 343-352. DOI: 10.7163/GPol.2014.23.

[5] Arjana, I G. B. 2016. Geografi pariwisata dan ekonomi kreatif. Rajawali Press. Jakarta.

[6] Banyuwangi Regency. Barong Ider Bumi ritual tolak bala ala suku Osing Banyuwangi. Available at: https://www.banyuwangikab. go.id/berita-daerah/barong-ider-bumiritual-tolak-bala-ala-suku-osingbanyuwangi.html

[7] Denzin, N. K. and Y. S. Lincoln. 2009. Handbook of qualitative research. Pustaka Pelajar. Yogyakarta.

[8] Sumarmi, S. 2015. Local wisdom of Osing People in conserving water resources. Komunitas: International Journal of Indonesian Society and Culture 7(1), 43-51. DOI: 10.15294/komunitas.v7i1.3429.

[9] Herawati, I. 2004. Kearifan lokal di lingkungan masyarakat Using, Kabupaten Banyuwangi, Propinsi Jawa Timur. Yogyakarta Traditional Values and Study Center. Yogyakarta.

[10] Dirgantara, S. D. 2017. Filosofi Barong Osing sebagai pembentuk tatanan nilai dan norma dalam kehidupan masyarakat Desa Kemiren, Banyuwangi. Paper in National Scientific Writing Competition, Departement of History, Faculty of Social Science, Universitas Negeri Malang, Malang.

[11] Sari, A. M., Sumarno, and Sumardi. 2014. Dinamika Upacara adat Barong Ider Bumi sebagai obyek wisata budaya Using di Desa Kemiren Kecamatan Glagah Kabupaten Banyuwangi tahun 1830-2014. University of Jember. Jember.

[12] Ariani, C. 2012. Seni tradisi Barong dan mitologi masyarakat Using. Jurnal Patrawidya Seri Penerbitan Sejarah dan Budaya 13(3), 433-462.

[13] Sulistyani. 2010. Ritual Ider Bumi di Desa Kemiren, Kecamatan Glagah, Kabupaten Banyuwangi. Jurnal Mudra 22, 28-38.

[14] Abdalla, U. A. 2002. Serat centhini, sinkretisme islam, dan dunia orang jawa 
Tourism Geography of Barong Ider Bumi Cultures in Banyuwangi (Khakim, et al.)

dalam bentara esei-esei. Buku Kompas. Jakarta.

[15] Budhisantoso, S., Sumarsono, H. Aswan, Rosyadi, and Suhardi. 1994. Nilai-nilai kemasyarakatan pada masyarakat Using di Banyuwangi. Department of Education and Culture. Banyuwangi.

[16] Sujarno. 2012. Tradisi sedekah bumi di Punthuk Setumbu Desa Karangrejo, Kecamatan Borobudur (Kajian kearifan lokal di Kabupaten Magelang). Jurnal Patrawidya Seri Penerbitan Sejarah dan Budaya 13(4), 565.

[17] Wirahayu, Y. A., H. Purwito, and N. Insani. 2019. Community-based tourism management in Santen Beach, Banyuwangi. IOP Conference Series: Earth and Environmental Science 243(1). DOI: 10.1088/1755-1315/243/1/012059.

[18] Suwantoro, G. 2007. Dasar-dasar pariwisata. Andi Publisher. Yogyakarta.

[19] Williams, S. 1998. Tourism geography. Routledge. Oxford.

[20] Wahab, S. 2003. Manajemen kepariwisataan. Pradnya Paramita. Jakarta

[21] Khakim, M. N. L., A. Fabian, G. Y. Prasetiyo, and S. Mutiara. 2019. Museum Musik Indonesia sebagai wisata edukasi di Kota Malang. Jurnal Pendidikan Sejarah 8(1), 6778. DOI: $10.21009 / J P S .081 .06$

[22] Khakim, M N L, Yuliati, O. Winasari, and S. Y. S. Asri, 2020. Identification of tourism potentials in Ancient Bathing Sites of Pasuruan, Indonesia. IOP Conference Series: Earth and Environmental Science 485, 012099. DOI: 10.1088/17551315/485/1/012099. 